\title{
Prototype Sampah Otomatis untuk menunjang Pola Hidup Sehat di era New Normal
}

\author{
Churnia Sari*1, Ahmad Zaki ${ }^{2}$, Iman Risky Juliana ${ }^{3}$ \\ 1,2,3 Universitas PGRI Madiun, Indonesia, Fakultas Teknik, Prodi Teknik Elektro \\ e-mail: *1s.churnia@unipma.ac.id, ${ }^{2}$ ahmadzakie1998@gmail.com, \\ 3imanrisky9@gmail.com
}

\begin{abstract}
Abstrak
Pada masa pandemi kebersihan dan kesahatan menjadi kunci utama kehidupan. Untuk menunjang kehidupan yang bersih dan sehat, tempat sampah menjadi salah satu hal yang sangat dibutuhkan keberadaannya. Klasifikasi tempat sampah yang ada, sudah cukup bagus untuk memudahkan teknologi daur ulang sebagai penunjang perbaikan lingkungan. Dengan adanya klasifikasi, sampah yang basah dan kering tidak akan tercampur. Sampah daur ulang juga langsung bisa ditangani tanpa harus memililah-milah terlebih dahulu. Selain klasifikasi sampah, Model sampah saat ini juga harus menjadi perhatian. Model sampah yang tidak efektif menjadi cukup beresiko untuk menularkan penyakit, terlebih virus covid-19 yang menjadi pandemi saat ini mampu bertahan pada permukaan plastik dalam jangka waktu yang cukup lama. Untuk mengatasi masalah tersebut, sekaligus menunjang kebersihan agar semakin terjaga maka dirancang sebuah penelitian terkait dengan Prototype Sederhana sampah Otomatis yang ramah lingkungan. Dari hasil penelitian didaptkan bahwa prototype sampah ini dapat menunjang kebersihan sekaligus kesehatan masyarakat secara efektif. Karena masyarakat tidak harus lagi membuka dan menutup sampah ketika hendak mebuang sampah, sehingga diharapkan masyarkat tidak malas untuk membuang sampah pada tempatnya.
\end{abstract}

Kata kunci-Bersih, New normal, Prototype sampah, Sampah otomatis

\begin{abstract}
During a pandemic, hygiene and health are the main keys to life. To support a clean and healthy life, garbage is one of the things that its existence needs. Existing garbage classification was good enough to facilitate recycling technology and support environmental improvement. With the classification, wet and dry trash will not be mixed. Recycled trash can also be handled immediately without having to sort it out first. Apart from garbage classification, the current garbage model should also be a concern. The ineffective garbage model is quite risky to transmit disease, especially the Covid-19 virus, which is currently a pandemic, can survive on plastic surfaces for a long time. To overcome these problems, as well as to support cleanliness, a study related to the Simple Prototype of automatic garbage was designed. From the results, it was found that the prototype, could effectively support cleanliness and public health. Because people no longer have to open and close trash when they want to dispose of trash, it is hoped that the human will not be lazy to throw the trash in itsplace.
\end{abstract}

Keywords-Automatic trash-can, Clean, New normal, Prototype trash-can 


\section{PENDAHULUAN}

Covid-19 telah melanda hampir seluruh negara di dunia. Meskipun pada beberapa negara penyebaran virus corona ini sudah dapat dikendalikan, namun faktanya masih terdapat negara-negara dengan pertambahan jumlah kasus positif corona (Covid-19) masih cenderung bertambah. Salah satu negara dengan kasus pertambahan positif Covid-19 yang belum mengalami penurunan adalah di Indonesia. Penambahan kasus di Indonesia membuktikan bahwa penyebaran virus ini cukup masif sehingga banyak dari masyrakat masih tertular. Kondisi ini diperparah dengan tidak adanya gejala yang signifikan pada beberapa orang sehingga mereka tidak sadar bahwa mereka mempunyai potensi untuk bisa menularkan ke orang lain [1].

Berdasarkan jurnal yang telah diterbitkan oleh $[2,3,4]$ menyatakan bahwa virus ini dapat menular memalui beberpa perantra selain dari manusia ke manusia, virus ini dapat bertahan pada beberpa permukaan benda dalam rentan waktu yang berbeda beda tergantung dari bahan permukaan benda tersebut. Oleh karena itu virus ini mampu menyebar dengan cukup cepat dan menjadi pandemi hampir di seluruh negara di dunia. Tempat umum dan berkumpulnya banyak orang menjadi hal yang paling dihindari agar tidak terjangkit virus ini. Pada tempat dan fasilitas umum, masyarakat dianjurkan untuk selalu memakai hand sanitzer setelah menyentuh permukaan benda-benda yang mempunyai potensi disentuh oleh banyak orang seperti ganggang pintu, mesin atm, telepon umum kantor atau tempat lainya, dan benda lain sejenisnya.

Krena hal tersebut, otomatisasi teknologi menjadi hal yang sangat penting. Teknologi jarak jauh juga semakin dikembangkan untuk mempermudah masyarakat agar tidak terlalu sering berinteraksi keluar rumah maupun bersinggungan secara langsung dengan tempat-tempat yang didalamnya terdapat potensi-potensi penyebaran virus ini. Salah satu yang bentuk sederhana dari teknologi otomasi tersebut sudah dapat dilihat pada kehidupan sehari sehari seperti pintu otomatis, pemindai wajah untuk absensi kehadiran, keran otomatis, dan banyak yang lainya. Semua aplikasi otomatisasi teknologi ini menjadi snagat bermanfaat ketika pandemi virus corona [5].

Para peneliti terus menerus mengembangkan berbagai model aplikasi otomatisasi teknologi dalam kehidupan sehari-hari, termasuk salah satunya adalah adanya inovasi tempat sampah pada fasilitas umum. Awalnya, tempat sampah hanyalah berupa wadah tanpa tutup dimana semua orang bisa memasukan sampah dengan mudah ke wadah tersebut. Karena bau sampah cukup mengganggu, dikembangkan sebuah sampah dengan tutup. Namun ketika pandemic berlangsung, sampah dengan tutup menjadi cukup beresiko karena seseorang yang hendak membuang sampah harus membuka tutup sampah dengan tangan atau kakinya. Menjadi sangat berbahaya jika sampah itu harus dibuka dengan tangan. Berdasarkan permasalahan tersebut, dibuat sebuah prototype yang sangat sederhana dan mudah diaplikasikan. Prototype sampah ini dibuat hanya dengan satu sensor dan menghasilkan fungsi manfaat yang cukup. Beberapa sampah otomatis yang sebelumnya pernah dibuat [6,7] sudah memberikan hasil yang optimal, namun masih menggunakan dua sensor yang bekerja bersamaan sehingga jika slah satu mati akan mengurangi fungsi manfaatnya.

Dalam penelitian ini, prototype sampah dibuat dengan satu sensor ultra sonic untuk membuka tutup sampah sekaligus memudahkan pengumpul sampah untuk memastikan apakah sampahnya sudah penuh tanpa harus membuka tutupnya dengan 
tangan. Desain yang sederhana ini dimaksudkan agar prototype sampah ini dapat dengan mudah diplikasikan pada sampah yang sebenarnya.

\section{METODE PENELITIAN}

\subsection{Sistem Open Loop}

Dalam sistem kendali otomatis atau teknik pengaturan, close loop dan open loop sistem merupakan dua hal utama yang mendasari komplek atau tidaknya sebuah teknik kendali. Begitu pula dalam menentukan algoritma yang harus digunakan, mengenali jenis dari sistem kendali yang diterapkan menjadi hal yang sangat penting. Dalam penelitian ini sistem yang diterpkan adalah sistem open loop. Pada dasarnya open loop sistem tidak membutuhkan kendali yang rumit untuk algoritmanya, karena dalam sistem ini, input dan outputnya tidak perlu update secara real time dan tidak perlu diperbaiki. Sistem open loop yang ada pada penelitian ini dijelaskan pada gambar 1 .

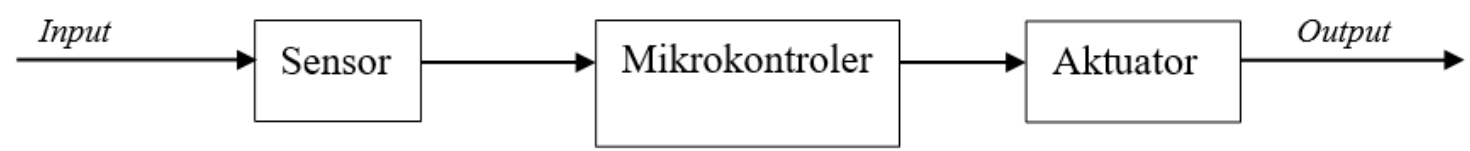

\section{Gambar 1 Diagram Sistem Open Loop Prototype Sampah Otomatis}

Berdasarkan gambar tersebut dapat diketahui bahwa sistem yang diterapkan pada sampah otomatis ini tidak memiliki feedback. Sensor pada penelitian ini menggunakan Sensor Ultrasonik. Sensor Ultrasonik dalam penelitian ini tidak digunakan sebagai komponen feedback tetapi digunakan sebgai pendeteksi adanya objek yang ada didekatnya. Jika ada objek dalam jarak kurang dari sama dengan $50 \mathrm{~cm}$ maka sensor ultrasonic akan memberikan aksi atau bernilai logika 1, jika tidak ada objek maka sensor tidak akan memberikan aksi apappun dan tetap pada kondisi awal dengan logika 0 .

\subsection{Prototype Sampah}

Prototype sampah pada penelitian ini terdiri dari kertas karton berukuran 40x20 $\mathrm{cm}$, lengkap dengan tutup di atasnya. Dilengkapi juga dengan sensor ultrasonik di bagian depan, dan mikrokontroler Arduino uno, serta motor servo sebagai penggerak tutupnya. Motor servo dan Arduino Uno mendapatkan sumber tegangan dari baterai sebesar 9V. Masing-masing bagian dan spesifikasi akan dijabarkan pada deskripsi di bawah ini. Fungsi sensor ultrasonik di sini adalah untuk mendeteksi ada atau tidaknya objek manusia yang hendak membuang sampah.

\subsubsection{Sensor Ultrasonik}

Sensor ultrasonic adalah sebuah sensor yang berfungsi untuk mengubah besaran fisis (bunyi) menjadi besaran listrik dan sebaliknya. Cara kerja sensor ini didasarkan pada prinsip pantulan gelombang suara sehingga dapat dipakai untuk menafsirkan eksistensi (jarak) suatu benda dengan frekuensi tertentu. Namun dalam penelitian ini sensor ultrasonic tidak digunakan sebagai pengukur jarak, melainkan digunakan sebagai pendeteksi objek yang mendekat dalam jarak tertentu yang sudah ditentukan yaitu $50 \mathrm{~cm}$. 


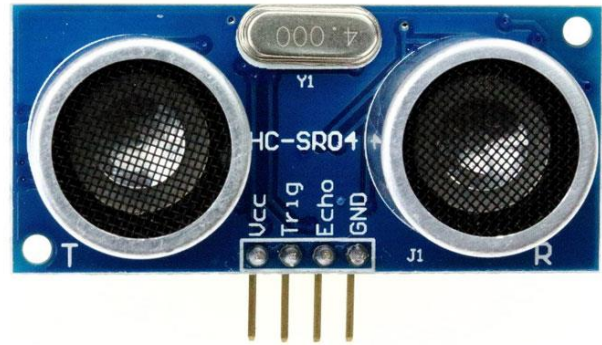

\section{Gambar 2 Sensor Ultrasonik HC-SR04}

Sensor ultrasonic yang digunakan pada penelitian ini adalah tipe HC-SR04, dengan spesifikasi: Working Voltage : 5V(DC), Working Current: max 15mA, Working frequency: $40 \mathrm{kHz}$, Output Signal: 0-5V (Output high when obstacle in range), Sentry Angle: max 15 degree, Sentry Distance: $2 \mathrm{~cm}$ - 4m, Measurement resolution: 0,3cm, Input trigger signal: 10us TTL impulse, Echo signal: output TTL PWL signal, Size : $45 \mathrm{~mm} \times 20 \mathrm{~mm} \times 15 \mathrm{~mm}$.

\subsubsection{Arduino Uno}

Arduino adalah pengendali mikro single-board yang bersifat open-source, diturunkan dari Wiring platform, dirancang untuk memudahkan penggunaan elektronik dalam berbagai bidang. Hardwarenya memiliki prosesor Atmel AVR dan softwarenya memiliki bahasa pemrograman sendiri. Bahasa yang dipakai dalam Arduino bukan assembler yang relatif sulit, tetapi bahasa $\mathrm{C}$ yang disederhanakan dengan bantuan pustaka-pustaka (libraries) Arduino. Arduino banyak digunakan karena kemudahan dalam penulisan syntaxnya dan cukup cepat untuk bisa dimengerti atau dipelajari. Arduino pada penelitian ini digunakan untuk integrasi seluruh komponen sekaligus penyimpan perintah pada sistem sampah otomatis ini. Tipe Arduino yang digunakan adalah Arduino UNO dengan spesifikasi: Microcontroller: ATmega328 SMD, Operating Voltage: 5V, Input Voltage (recommended): 7-10V, Digital I/O Pins: 14 (of which 6 provide PWM output), Analog Input Pins: 6, Flash Memory: $32 \mathrm{~KB}$ (ATmega328) of which $0.5 \mathrm{~KB}$ used by bootloader, SRAM: 2 KB (ATmega328). EEPROM: $1 \mathrm{~KB}$ (ATmega328), Clock Speed: $16 \mathrm{MHz}$, Operating Voltage: 5V, Input Voltage (recommended): 7-10V, Digital I/O Pins: 14 (of which 6 provide PWM output), Analog Input Pins: 6

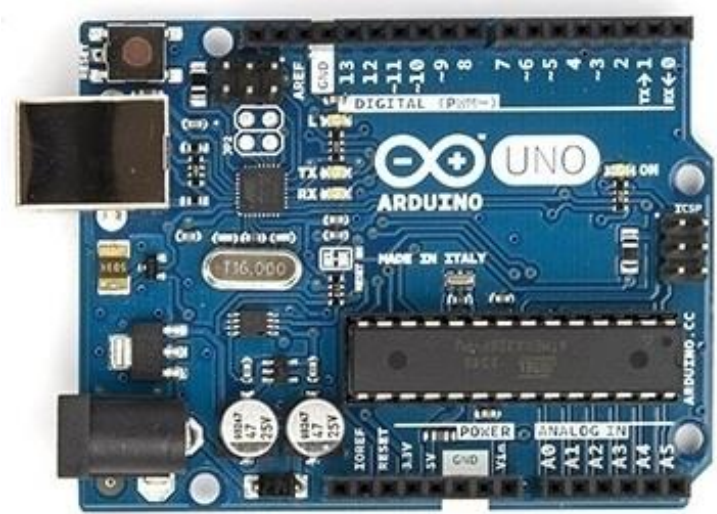

Gambar 3 Mikrokontroler Arduino Uno 


\subsubsection{Motor Servo}

Motor servo adalah sebuah perangkat berupa aktuator putar (motor). Perangkat ini terdiri dari motor DC, serangkaian gear, rangkaian kontrol dan potensiometer. Serangkaian gear yang melekat pada poros motor DC akan memperlambat putaran poros dan meningkatkan torsi motor servo, sedangkan potensiometer dengan perubahan resistansinya saat motor berputar berfungsi sebagai penentu batas posisi putaran poros motor servo. Motor servo pada penelitian ini berfungsi untuk membuka tutup sampah secara otomatis. Karena ukuran lengan serta torsi yang dihasilkan motor servo SG90 cukup kecil, maka bahan penutup sampah pada prototype ini dibuat seringan mungkin, serta diberi lengan tambahan modifikasi agar tutup sampah dapat terbuka secara sempurna. Spesifikasi dari SG90 adalah sebagai berikut Ukuran: $21.5 \mathrm{~mm}$ x $11.8 \mathrm{~mm}$ x 22.7mm, Berat: 9 gram, No-load speed: 0.12 detik / 60 derajat (4.8V), Stall torque: 1.2 $1.4 \mathrm{~kg} / \mathrm{cm}(4.8 \mathrm{~V})$, Suhu operasi: -30 to +60 derajat Celsius, Dead-set: 7 microseconds, Voltase: $4.8 \mathrm{~V}-6 \mathrm{~V}$.

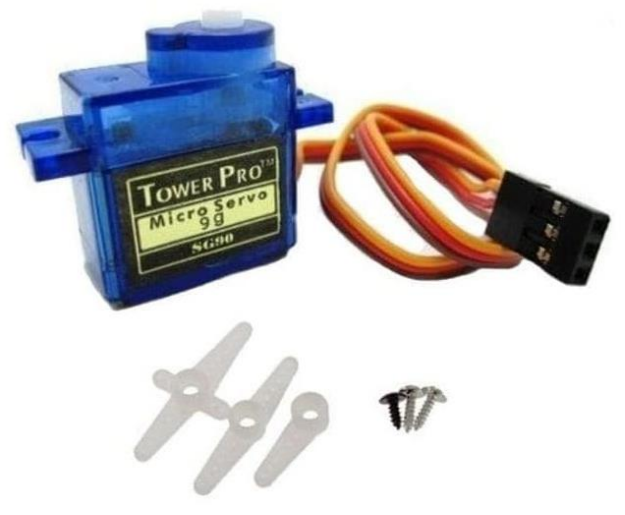

Gambar 4 Motor Servo SG90

\subsection{Perancangan Hardware Prototype Sampah}

Perancangan hardware pada penelitian ini sangat mudah dan sederhana, karena ini sampah ini masih dalam bentuk prototype maka seluruh hardware yang digunakan cukup mudah didapatkan dan dicari. Untuk bisa membuat prototype sampah ini dibutuhkan lima item penting yaitu: kertas karton atau sampah plastik dengan ukuran kecil atau sedang, dalam penelitian ini sampah yang digunakan berukuran $35 \times 15 \times 25$ $\mathrm{cm}$, Arduino UNO (bisa diganti dengan mikrokontroler tipe lain yang kapasitasn memorinya lebih kecil, karena pada dasarnya, algoritma yang digunakan cukup sederhana dan sedikit listing programnya), Sensor Ultrasonik, Motor Servo dan Sumber Tegangan DC (sumber tegangan DC pada penelitian ini berupa baterai 9V, akan lebih baik jika pada aplikasinya tidak digunakan baterai tapi digunakan sel surya untuk supply energi sehingga lebih compatible dan efektif karena tidak harus mengganti serta lebih tahan terhadap kondisi cuaca jika berada di luar ruangan). Berikut ini adalah sistem prototype sampah yang dirancang secara keseluruhan. 


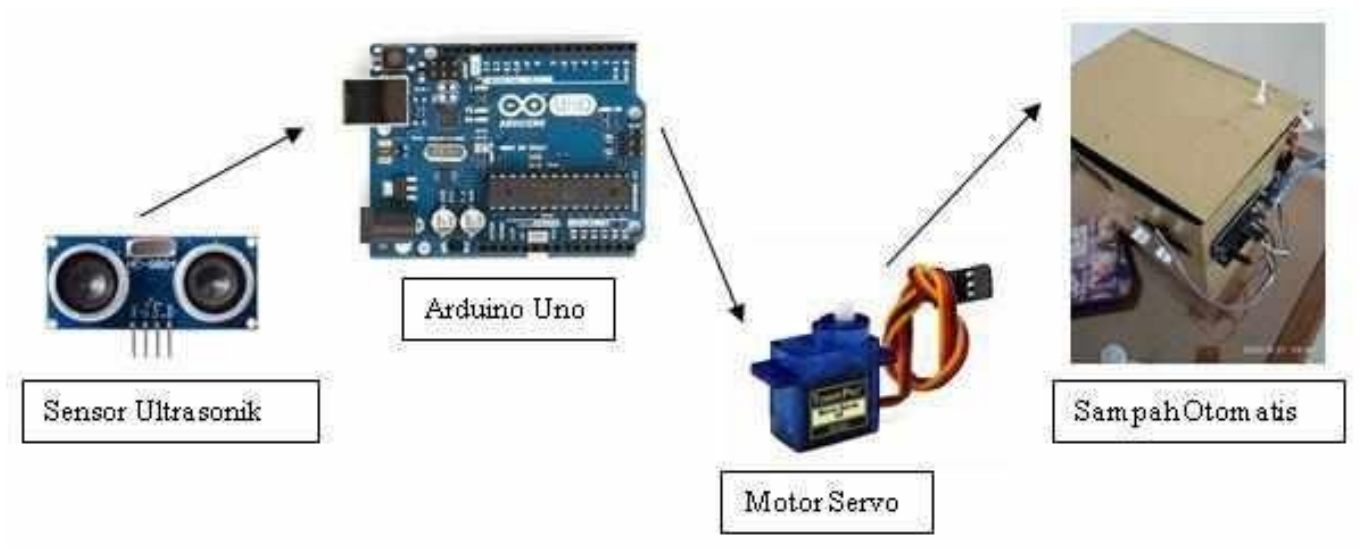

\section{Gambar 5 Skema Keseluruhan Sistem}

Cara kerja Prototype sampah Otomatis ini adalah sebagai berikut: ketika ada objek manusia yang mendekat pada jarak kurang dari sama dengan $50 \mathrm{~cm}$, maka sensor ultrasonik akan memberikan nilai HIGH ke Arduino, kemudian Arduino memberikan perintah HIGH ke Motor Servo, sehingga motor servo akan bergerak dengan putaran maksimum untuk membuka tutup sampah kemudian dalam waktu 50 detik sampah akan tertutup kembali.

\subsection{Algoritma Sistem}

Algoritma yang digunakan dalam sistem ini dapat dilihat pada gambar 6 .

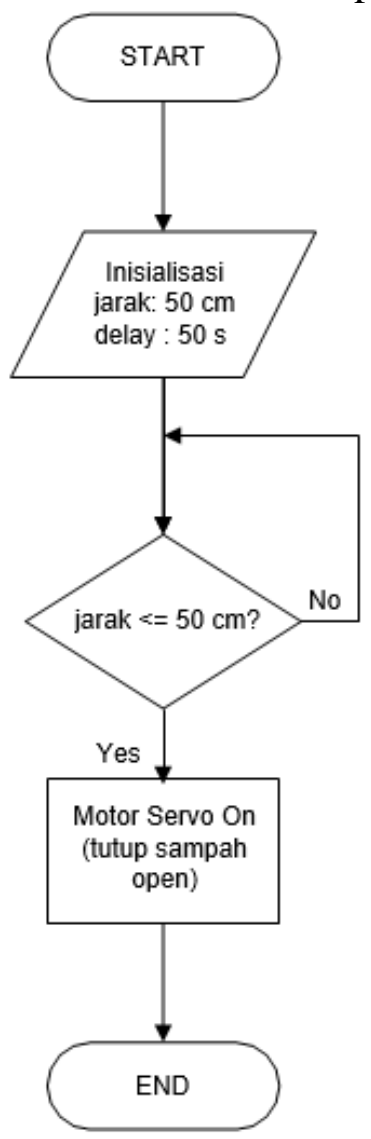

Gambar 6 Flowchart Algoritma Sistem 
Berikut adalah listing program pada Arduino:

void $\operatorname{loop}()\{$

// put your main code here, to run repeatedly:

for (int $\mathrm{i}=0 ; \mathrm{i}<=2 ; \mathrm{i}++)\{$

measure();

aver[i] $=$ dist;

$\operatorname{delay}(50) ;\}$

dist $=(\operatorname{aver}[0]+$ aver$[1]+\operatorname{aver}[2]) / 3$;

if $($ dist $<=50)\{$

servo.attach(servoPin);

$\operatorname{delay}(1)$;

servo.write(180);

delay $(5000)$;

servo.write $(0)$;

delay(1000); \}

Dari data tersebut dapat dilihat bahwa ketika objek berada kurang dari sama dengan $50 \mathrm{~cm}$ maka motor servo akan bergerak 180 derajat sehingga tutup menjadi terbuka.

\section{HASIL DAN PEMBAHASAN}

\subsection{Pengujian Sensor Ultrasonik}

Sebelum diintegrasikan pada keseluruhan sistem sensor ultrasonik akan dikalibrasi terlebih dahulu untuk memastikan bahwa sensor ulotrasonik dapat bekerja dengan baik. Setelah kalibarasi kinerja sensor HR04 menjadi lebih akurat dalam menentukan jarak dengan error relatif kurang dari 1\%. Tabel dibawah ini adalah hasil pembcaan sensor ultrasonic ketika pengujian objek sebenarnya dengan hasil pembacaan sensor ultrasonik.

Tabel 1 Hasil Pembacaan Sensor Ultrasonik Sebelum dan Sesudah Kalibrasi

\begin{tabular}{ccc}
\hline Ukuran Sebenarnya & Sebelum Kalibarasi & Setelah Kalibrasi \\
\hline $\mathbf{1 1} \mathbf{~ c m}$ & $9.89 \mathrm{~cm}$ & $11.07 \mathrm{~cm}$ \\
$\mathbf{1 8 ~ c m}$ & $16.6 \mathrm{~cm}$ & $18.0 \mathrm{~cm}$ \\
$\mathbf{2 0} \mathbf{~ c m}$ & $18.56 \mathrm{~cm}$ & $19.94 \mathrm{~cm}$ \\
$\mathbf{3 0} \mathbf{~ c m}$ & $28.6 \mathrm{~cm}$ & $29.90 \mathrm{~cm}$ \\
$\mathbf{5 0} \mathbf{~ c m}$ & $47.76 \mathrm{~cm}$ & $49.89 \mathrm{~cm}$ \\
\hline
\end{tabular}

\subsection{Pengujian Motor Servo}

Sama halnya dengan sensor ultrasonik dalam penelitian ini Motor Servo juga akan diuji kinerja putaran yang dihasilkan. Tabel 2 adalah output putaran yang dihasilkan motor servo ketika diberi perintah oleh Arduino. Motor Servo tidak bisa mencapai nilai maksimal ketika harus berputar $180^{\circ}$ bukan karena error dari instrument tapi karena lengan bantuan yang dipasang cukup berat dan panjang $\pm 12 \mathrm{~cm}$. Karena motor servo membutuhkan torsi yang cukup besar untuk berputar, baterai yang digunakan pun menjadi tidak efektif karena cepat sekali habis. Oleh karena itu dibuat 
power supply sebagai input tegangan DC untuk prototype sampah ini. Namun dalam aplikasi yang sesugguhnya akan lebih baik jika sumber energi memiliki desain yang sederhana, tahan cuaca dan juga portable.

Tabel 2 Output Putaran Motor Servo

\begin{tabular}{cc}
\hline Pada Arduino & Realisasi Motor Servo \\
\hline $\mathbf{4 5}^{\circ}$ & $45^{\circ}$ \\
$\mathbf{9 0}^{\circ}$ & $90^{\circ}$ \\
$\mathbf{1 8 0}^{\circ}$ & $178^{\circ}$ \\
\hline
\end{tabular}

\subsection{Hasil Perancangan Hardware}

Hasil perancangan Hardware dapat dilihat pada Gambar 7. Dari penjelasna yang sudah dijabarkan, dapat dilihat dengan jelas bahwa secara keseluruhan integrasi antara sensor dan actuator bekerja dengan baik. Namun pada Gambar dapat dilihat bahwa desain dari prototype ini masih butuh sekali banyak perbaikan. Karena mikrokontroler dan sensor tidak akan bisa bertahan lama jika terkena air atau pun tidak sengaja tertabrak atau terlepas. Sehingga butuh desain khusus untuk memberikan ruang pada alat-alat elektronik tersebut agar terlindung dari segala sesuatu yang membuat komponen-komponen itu kehilangan fungsi kerjanya. Dan karena dalam sistem protoype sampah ini, algortima yang digunakan sangat sederhana akan lebih baik lagi jika mikrokontrolernya menggunakan tipe mini (Arduino Mini) selain efektif dan mudah untuk ditempatkan, juga membuat desain lebih menarik.

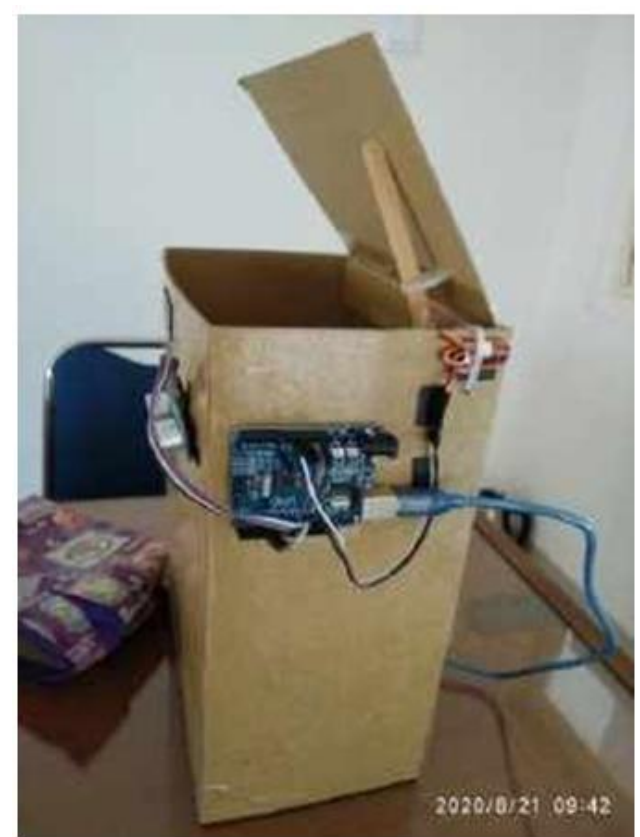

Gambar 7 Desain Prototype Sampah Otomatis 


\section{KESIMPULAN}

Berdasarkan hasil yang telah dijelaskan sebelumnya, maka dapat diambil kesimpulan bahwa:

1. Algortima yang dirancang untuk prototype sampah otomatis ini dapat bekerja dengan baik dan sampah dapat terbuka (motor servo dapat berputar maksimal sampai $178^{\circ}$ ) dan menutup kembali secara otomatis ketika ada objek yang datang mendekat pada jarak kurang dari sama dengan $50 \mathrm{~cm}$ dan akan tertutup kembali setelah 50 detik.

2. Desain dari peletakan instrument elektronika pada prototype ini masih butuh banyak perbaikan, serta dapat diketahui bahwa baterai tidak efektif sebagai sumber tegangan pada perancangan prototype sampah ini, akan lebih efektif jika ada sumber tegangan lain yang mempunyai kapasitas lebih besar dengan desain yang lebih sederhana.

\section{DAFTAR PUSTAKA}

[1] W. Wiguna dan D. Riana, "Diagnosis of coronavirus disease 2019 (Covid-19) surveillance using C4.5 algortihm," Jurnal PILAR Nusa Mandiri, vol. 16, no. 1, pp. 71-80, 2020.

[2] W. Dwi Nugroho dkk, "Literature review: Transimisi Covid-19 dari manusia ke manusia di Asia," Jurnal of Bionursing, vol. 2, no. 2, pp. 101-112, 2020.

[3] L. Fiorillo et al, "Covid-19 surface persistence: A recent data summary and its importance for medical and dental setting," International Journal Environmental Research and Public Health, vol. 17, no. 3132, pp. 1-10, 2020.

[4] N. Mona, "Konsep isolasi dalam jaringan sosial untuk meminimalisasi efek contagoius (kasus penyebaran virus corona di Indonesia)," Jurnal Sosial Humaniora Terapan, vol. 2, no. 2, pp. 117-125, januari-Juni 2020.

[5] E. R. Madurai and R. Pugazhendhi, "Restructured society and environment: A review on potential technological strategies to control the COVID-19 pandemic," Science of The Total Environment, vol. 725, no. 138858, pp. 1-18, July 2020.

[6] H. P. Putra and S. N. Wahid, "Pembuatan trainer tempat sampah otomatis guna menyiasati masalah sampah di lingkungan masyarakat," Jurnal of Electrical and Electronic Engineering, vol. 3, no. 1, pp. 120-137, April 2019.

[7] H. D. Ariessanti, Martono and J. Widiarto, "Sistem pembuangan sampah otomatis berbasis IoT menggunakan mikrokontroler pada SMAN 14 Tangerang," CCIT Journal, vol. 12, no. 2, pp. 229-240, Agustus 2019. 